\title{
Incorporating white clover (Trifolium repens L.) into perennial ryegrass (Lolium perenne L.) swards receiving varying levels of nitrogen fertilizer: Effects on milk and herbage production
}

\author{
M. Egan, N. Galvin, and D. Hennessy ${ }^{1}$ \\ Teagasc, Animal \& Grassland Research and Innovation Centre, Moorepark, Fermoy, Co. Cork, Ireland P61 C996
}

\begin{abstract}
White clover (Trifolium repens L.; clover) can offer a superior nutritional feed compared with perennial ryegrass (Lolium perenne L.; PRG) and offers an additional or alternative source (or both) of $\mathrm{N}$ for herbage production. The objective of this study was to investigate the effect of including clover into PRG swards receiving 150 (Cl150) or $250 \mathrm{~kg}$ of N/ha (Cl250) compared with a PRG-only sward receiving $250 \mathrm{~kg}$ of N/ha (Gr250) on herbage production, milk production, and herbage dry matter intake (DMI) in an intensive grass-based spring calving milk production system over 2 full lactations. A farm systems experiment was established in February 2013, and conducted over 2 grazing seasons [2013 (yr 1) and 2014 (yr 2)]. In February 2013 (yr 1), 42 Holstein-Friesian spring-calving dairy cows, and in February 2014 (yr 2), 57 Holstein-Friesian springcalving dairy cows were allocated to graze the Cl150, $\mathrm{Cl} 250$, and Gr250 swards ( $\mathrm{n}=14$ in yr 1 and $\mathrm{n}=19$ in yr 2) from February to November, at a stocking rate of 2.74 cows/ha. Herbage DMI was estimated twice in yr 1 (May and September) and 3 times in yr 2 (May, July, and September). Treatment did not have a significant effect on annual herbage production. Sward clover content was greater on the Cl150 treatment than the Cl250 treatment. The cows grazing both clover treatments (Cl250 and C1150) produced more milk than the cows grazing Gr250 from June until the end of the grazing season. A significant treatment by measurement period interaction was observed on total DMI. In May, the cows on the Cl250 treatment had the greatest DMI. In July, the cows on the clover treatments had greater DMI than those on the Gr250 treatment, whereas in September, the cows on the Cl150 treatment had the lowest DMI. In conclusion, including clover in a PRG sward grazed by spring-calving dairy cows can result in increased animal performance, particularly in the
\end{abstract}

Received May 25, 2017.

Accepted December 10, 2017

${ }^{1}$ Corresponding author: Deirdre.Hennessy@teagasc.ie second half of lactation. Reducing $\mathrm{N}$ fertilizer application to $150 \mathrm{~kg}$ of $\mathrm{N} / \mathrm{ha}$ on grass-clover swards did not reduce herbage production compared with grass-only swards receiving $250 \mathrm{~kg}$ of N/ha. White clover can play an integral role in intensive grazing systems in terms of animal performance and herbage production.

Key words: white clover, perennial ryegrass, nitrogen, milk production, dry matter intake

\section{INTRODUCTION}

Pasture-based milk production systems in temperate regions are generally low cost because grazed grass is the primary feed source for dairy cows (Clark et al., 2007; Finneran et al., 2012). To maintain competitiveness, pasture-based dairy production systems must efficiently convert high-quality grazed pasture into milk (Dillon et al., 2008; Chapman et al., 2017). Increased milk production must occur through increased herbage production and utilization (Dillon et al., 2008) if grassbased systems are to remain profitable.

The objective of intensive pasture-based dairy production systems is to maximize milk production from grazed pasture grass (Penno, 2000; Dillon et al., 2008; Humphreys et al., 2008). Perennial ryegrass (Lolium perenne L.; PRG) is the predominant forage species used in grazing systems in temperate regions of the world (Fulkerson et al., 2007). Good grazing management practices (O'Donovan et al., 2011) can result in improved feed quality and to a certain extent negate some of the climatic and seasonal effects (Dillon et al., 2008) on pasture quality. The increasing stem proportion of the PRG plant in mid-summer can result in reduced herbage quality (Ulyatt et al., 1988; Hennessy et al., 2008; Wims et al., 2013) and subsequently reduced animal performance (Blaser, 1964; Wims et al., 2013). It has long been recognized that white clover (Trifolium repens L.; hereafter referred to as clover) provides a forage nutritionally superior to PRG (Thomson and Raymond, 1970) and offers an alternative to $\mathrm{N}$ fertilizer application or an additional source of $\mathrm{N}$ for the sward for herbage production (Ledgard and Steele, 1992; Phillips and James, 1998). 
Intensive pasture-based systems usually rely on high $\mathrm{N}$ fertilizer input to provide an adequate supply of good-quality herbage for grazing animals. In mixed PRG-clover swards, however, clover can offer an alternative source of N. Ledgard and Steele (1992) and Schils et al. (1999) found that increasing the $\mathrm{N}$ fertilizer application can result in a reduction in sward clover content. Recently, Nyfeler et al. (2011) under cutting and Enriquez-Hidalgo et al. (2014a, 2016) and Egan et al. (2017) under grazing have succeeded in maintaining a high sward clover content $(>20 \%)$ in swards receiving high levels of $\mathrm{N}$ fertilizer $(>200 \mathrm{~kg}$ of $\mathrm{N} / \mathrm{ha}$ ). Sward management practices such as frequent (Harris and Clark, 1996; McKenzie et al., 2003) and tight ( $\leq 4 \mathrm{~cm}$; $\mathrm{Yu}$ et al., 2008; Phelan et al., 2013) grazing have been shown to maintain or increase sward clover content in high $\mathrm{N}$ fertilizer application systems.

The benefits of clover for milk production have been reported in short-term component and indoor feeding experiments (Thomson et al., 1985; Harris et al., 1998) and full-season grazing studies (Egan et al., 2017). In grazed PRG-clover swards, an increase in milk production can occur due to a combination of both feed quality and intake factors (Clark and Harris, 1996; Harris et al., 1998). In high-stocking-rate ( $>2.5$ cows/ha) pasture-based systems, clover is usually omitted due to high $\mathrm{N}$ application rates and the likely reduction in sward clover content due to high N input (Reid, 1970; Frame and Newbould, 1986; Davies, 1992), as well as the likely damage to clover stolons from treading and burial (Davies, 1992). Usually, in grass-clover systems $\mathrm{N}$ application rate is reduced, and stocking rate is lower than on grass-only high $\mathrm{N}$ systems [e.g., Humphreys et al. (2009) and Schils et al. (2000)].

Enriquez-Hidalgo et al. (2014a) and Egan et al. (2017) found similar herbage production on intensively grazed (8-9 times per year) grass-clover swards receiving $250 \mathrm{~kg}$ of $\mathrm{N} /$ ha compared with grass-only swards receiving $250 \mathrm{~kg}$ of $\mathrm{N} / \mathrm{ha}$. Consequently, it is likely that some reduction in $\mathrm{N}$ application to grass-clover systems at high stocking rate $(>2.5$ cows/ha) may be possible. Therefore, the objective of this study was to investigate the effect of including clover in PRG swards receiving 150 or $250 \mathrm{~kg}$ of $\mathrm{N} /$ ha compared with a PRG-only sward receiving $250 \mathrm{~kg}$ of $\mathrm{N} / \mathrm{ha}$ on herbage production, milk production, and herbage DMI in an intensive grass-based spring-calving dairy production system.

\section{MATERIALS AND METHODS}

\section{Experimental Site and Meteorological Data}

The experiment was undertaken at Teagasc, Animal \& Grassland Research and Innovation Centre, Moore- park, Fermoy, Co. Cork, Ireland $\left(52^{\circ} 16^{\prime} \mathrm{N} ; 8^{\circ} 25^{\prime} \mathrm{W} ; 49\right.$ $\mathrm{m}$ above sea level) in 2013 and 2014 . The soil type was a free-draining acid brown earth of sandy loam-to-loam texture. Soils had a pH of 6.4 and were index 3 and 4 (scale 1 to $4,1=$ deficient, $4=$ no response to application of nutrient; Alexander et al., 2008) for phosphorus and potassium.

Meteorological data, daily rainfall $(\mathrm{mm})$, air temperatures $\left({ }^{\circ} \mathrm{C}\right)$, and soil temperature at a depth of 100 $\mathrm{mm}\left({ }^{\circ} \mathrm{C}\right)$, for the experimental period were collected at the experimental site.

\section{Experimental Design}

A farm systems experiment was established in February 2013 and conducted over 2 grazing seasons [February 16 to November 18, 2013 (yr 1) and February 17 to November 21, 2014 (yr 2)]. A total of 15.33 ha in yr 1 and 21.89 ha in yr 2 of permanent grassland were used for the experiment. In July 2012, 7.8 ha was reseeded, 2.6 ha with a 50:50 mixture of Astonenergy (tetraploid) and Tyrella (diploid) PRG cultivars sown at a rate of $27.2 \mathrm{~kg} / \mathrm{ha}$, and $5.2 \mathrm{ha}$ with the same PRG mixture plus a 50:50 mixture of Chieftan and Crusader medium leaf clover cultivars sown at a rate of $5 \mathrm{~kg} / \mathrm{ha}$. In June 2013, a further 6.14 ha was reseeded, 2.04 ha with the PRG grass mixture, and 4.09 ha with the PRG and clover mixture. The additional area (7.53 ha in yr 1 and 7.94 ha in yr 2) used in the study consisted of existing PRG swards, cv. Tyrella, sown in 2010 at a rate of $29 \mathrm{~kg} / \mathrm{ha}$ and PRG (cv. Tyrella, $29 \mathrm{~kg} / \mathrm{ha}$ )/clover (cv. Chieftain and Crusader, 50:50 mix at $5 \mathrm{~kg} / \mathrm{ha}$ ) swards established in 2010. All paddocks, both newly reseeded and existing paddocks, were blocked and evenly distributed among each sward type. A separate farmlet of 7 paddocks in yr 1 and 11 paddocks in yr 2 was created and permanently fenced for each of the 3 sward types (treatments), a PRG/clover sward receiving $150 \mathrm{~kg}$ of $\mathrm{N} /$ ha per yr (Cl150), PRG/clover sward receiving 250 $\mathrm{kg}$ of N/ha per yr (Cl250) and a PRG-only sward receiving $250 \mathrm{~kg}$ of N/ha per yr (Gr250). The total area of each treatment was 5.11 ha in yr 1 and 7.3 ha in yr 2. Within each farmlet, there were detailed measurement paddocks for each treatment (approximately 2 ha per treatment, reseeded in 2012). These paddocks were used to measure tiller density, stolon mass, and DMI. All other sward measurements, as outlined later, were conducted on all paddocks within each farmlet.

Swards received either $250 \mathrm{~kg}$ of N/ha or $150 \mathrm{~kg}$ of $\mathrm{N} /$ ha per yr, depending on treatment. Nitrogen was applied to all treatments as urea $(46 \% \mathrm{~N})$ until the end of April and as calcium ammonium nitrate $(27 \% \mathrm{~N})$ from early May to mid-September (Table 1). Nitrogen fertil- 
Table 1. Annual $\mathrm{N}$ fertilizer application regimen ${ }^{1}$

\begin{tabular}{llccc}
\hline Application & Date & $\mathrm{Cl}^{2} 50^{2}(\mathrm{~kg}$ of N/ha) & $\mathrm{Cl} 250^{3}(\mathrm{~kg}$ of N/ha) & $\mathrm{Gr} 250^{4}(\mathrm{~kg}$ of N/ha) \\
\hline 1 & Mid-January & 28 & 28 & 28 \\
2 & March & 28 & 28 & 28 \\
3 & April & 28 & 33 & 33 \\
4 & Early May & 9 & 33 & 33 \\
5 & Late May & 9 & 27 & 17 \\
6 & June & 9 & 17 & 17 \\
7 & Early July & 9 & 17 & 17 \\
8 & Late July & 9 & 17 & 33 \\
9 & August & 12 & 33 & 250 \\
10 & September & 150 & 250 & 37 \\
Total & & 9 & & 27 \\
\hline
\end{tabular}

${ }^{1}$ Nitrogen applied in mid-January and March was applied as urea $(46 \% \mathrm{~N})$, and the remainder was applied as calcium ammonium nitrate $(27 \% \mathrm{~N})$.

${ }^{2} \mathrm{Cl} 150=$ grass and white clover swards receiving $150 \mathrm{~kg}$ of $\mathrm{N} / \mathrm{ha}$ per $\mathrm{yr}$.

${ }^{3} \mathrm{Cl} 250=$ grass and white clover swards receiving $250 \mathrm{~kg}$ of $\mathrm{N} /$ ha per $\mathrm{yr}$.

${ }^{4} \mathrm{Gr} 250=$ grass-only swards receiving $250 \mathrm{~kg}$ of N/ha per yr.

izer was broadcast using an Abbey fertilizer applicator (Abbey Machinery, Nenagh, Co. Tipperary, Ireland).

In February of yr 1, 42 Holstein-Friesian (9 primiparous and 33 multiparous) spring-calving dairy cows were selected and blocked according to calving date, lactation number, 2-wk pre-experimental daily milk yield, milk fat, milk protein, and milk solids yield, and then randomly assigned to 1 of the 3 treatments $(\mathrm{n}=$ 14; Table 2). In February of yr 2, 57 Holstein-Friesian (18 primiparous and 39 multiparous) spring-calving dairy cows were selected and blocked according to calving date, lactation number, 2 -wk pre-experimental daily milk yield, milk fat, milk protein, and milk solids yield, and then randomly assigned to 1 of the 3 treatments $(\mathrm{n}=19$; Table 2). Additionally, in yr 2, one additional cow was included in each treatment to maintain a stocking rate of 2.74 cows/ha, and that cow's data were not included in the statistical analysis. All experimental procedures involving cows were approved by the Teagasc Animal Ethics Committee and authorized by the Health Products Regulatory Authority, which is the competent authority in Ireland responsible for the implementation of European Union legislation
(Directive 2010/63/EU; European Council, 2010) for the protection of animals used for scientific purposes.

\section{Animal and Grazing Management}

Nine grazing rotations were used on each treatment (February to November) in both years. Herbage mass (HM) and sward clover content were measured in each paddock before each grazing, and data presented are mean values of each rotation. Target pregrazing HM (4 $\mathrm{cm}$ above ground level; $>4 \mathrm{~cm}$ ) was 1,300 to $1,600 \mathrm{~kg}$ of $\mathrm{DM} /$ ha for the duration of the experiment. Cows were turned out to grass by day and night as they calved from early February in both years. During the first grazing rotation, all treatments were allocated pasture according to the spring rotation planner (Teagasc, 2009). Swards were rotationally grazed and on-off grazing (Kennedy et al., 2009) was used as a management tool to facilitate grazing during periods of inclement weather. Break fences allowed a fresh allocation of pasture to be offered after each morning and evening milking during the first rotation (February to early April). Subsequently fresh herbage was allocated every 24 to 36

Table 2. Initial herd characteristics for the animals used in the experiment in 2013 and 2014

\begin{tabular}{|c|c|c|c|c|}
\hline Item & 2013 & SD & 2014 & $\mathrm{SD}$ \\
\hline Mean calving date & February 1 & 6.5 & February 7 & 14.9 \\
\hline Mean lactation number & 2.90 & 1.47 & 2.75 & 1.55 \\
\hline Mean pre-experimental daily milk fat (\%) & 4.48 & 0.62 & 4.76 & 0.53 \\
\hline Mean pre-experimental daily milk protein (\%) & 3.38 & 0.25 & 3.24 & 0.20 \\
\hline Mean pre-experimental daily milk solids ( $\mathrm{kg} / \mathrm{cow}$ ) & 1.88 & 0.38 & 2.23 & 0.45 \\
\hline Herd EBI $(€)^{1}$ & 155 & 34.7 & 165 & 37.1 \\
\hline
\end{tabular}

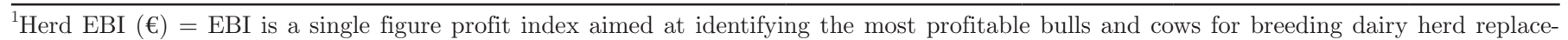
ments. It comprises information on 7 sub-indexes related to profitable milk production. More information is available at www.icbf.com. 
$\mathrm{h}$ for the remainder of the experiment following morning or evening milking. The area allocation was based on herbage available $>4 \mathrm{~cm}$. Target postgrazing sward height (PostGSH) was $<4 \mathrm{~cm}$ in the first rotation, and $4 \mathrm{~cm}$ for the remainder of the year. Fresh water was continuously available to the cows. Grass supply for each treatment was managed independently using the farm cover technique (O'Donovan et al., 2002). A visual assessment (O'Donovan et al., 2002) of pasture cover was undertaken weekly and recorded on PastureBase Ireland (Hanrahan et al., 2017), and grazing management decisions were made as described by Wims et al. (2014). Pasture surplus to grazing requirements was conserved as bale silage. Additionally, $33 \%$ of the land area in each treatment was closed for first-cut silage in early April for approximately $42 \mathrm{~d}$ and $25 \%$ of the land area in each treatment was closed for second-cut silage in early June for approximately $49 \mathrm{~d}$. All silage was conserved as bales.

All cows on each treatment received similar concentrate supplementation. Concentrate supplementation was used in the spring period (February to April) on all treatments and in the main grazing season (May to September) only when a herbage deficit occurred on all 3 treatments. If a deficit occurred on an individual treatment during the main grazing season, conserved silage from that treatment was fed to the cows. In yr 1, concentrates were fed, from February 16 to April 23, July 24 to July 31, and September 25 to November 18, a total of $496 \mathrm{~kg}$ of DM of concentrate/cow. In yr 2, concentrates were fed, from February 17 to April 9 and November 1 to November 21, a total of $272 \mathrm{~kg}$ of DM of concentrate/cow. The concentrate ingredients were as follows: maize (13\%), beet pulp/ molasses (15.5\%), soybean meal $(30 \%)$, maize distillers $(12 \%)$, acid buff $(0.7 \%)$, maize/beet $(2.5 \%)$ salt $(0.5 \%)$, barley (15\%), rapeseed meal $(7.5 \%)$, and Megalac (3.3\%; McDonnell Brothers Limited, Fermoy, Co. Cork, Ireland). The concentrate composition was $154.1 \mathrm{~g} / \mathrm{kg}$ of DM of CP $(40.9$ $\mathrm{g} / \mathrm{kg}$ of DM NDF and $102.8 \mathrm{~g} / \mathrm{kg}$ of DM ash. Swards were not topped (mechanically conditioned) during the experiment.

\section{Sward Measurements}

Herbage Mass. Pregrazing HM (>4 cm) was measured in each paddock of each treatment before grazing by cutting 2 strips $1.2 \mathrm{~m}$ wide and of a known length (approximately $8 \mathrm{~m}$ ) in the area due to be grazed next with an Etesia lawn mower (Etesia UK. Ltd., Warwick, UK). The harvested material was collected and weighed, and a $100-\mathrm{g}$ sub-sample was dried at $95^{\circ} \mathrm{C}$ for $16 \mathrm{~h}$ to determine the DM content. Compressed sward height was measured before and after harvesting on each cut strip by taking 10 measurements per strip using a rising plate meter with a steel plate (diameter 355 $\mathrm{mm}$ and $3.2 \mathrm{~kg} / \mathrm{m}^{2}$; Jenquip, Feilding, New Zealand) to determine sward density ( $\mathrm{kg}$ of $\mathrm{DM} / \mathrm{cm}$ per ha) using the following equation:

$$
\begin{aligned}
& \text { sward density ( } \mathrm{kg} \text { of } \mathrm{DM} / \mathrm{cm} \text { per ha })= \\
& \frac{\text { herbage mass }(\mathrm{kg} \text { of } \mathrm{DM} / \mathrm{ha})}{\text { precutting sward height - postcutting sward height }} \text {. }
\end{aligned}
$$

The average paddock pregrazing $\mathrm{HM}>4 \mathrm{~cm}$ was then calculated according to the following equation:

$$
\begin{gathered}
\text { pregrazing } \mathrm{HM}>4 \mathrm{~cm}(\mathrm{~kg} \text { of DM} / \mathrm{ha})= \\
\text { [pregrazing sward height }(\mathrm{cm})-4 \mathrm{~cm}] \\
\times \text { sward density }(\mathrm{kg} \text { of } \mathrm{DM} / \mathrm{cm} \text { per ha })
\end{gathered}
$$

Pre- and Postgrazing Compressed Sward Heights. Pregrazing sward height (PreGSH) was recorded for each treatment by taking a minimum of 50 measurements in the area about to be grazed following a $\mathrm{W}$ shape across the area using the rising plate meter described previously. After grazing, a similar procedure was used to determine PostGSH above ground level.

Sward Clover Content. The sward clover was determined once in each $\mathrm{Cl} 150$ and $\mathrm{Cl} 250$ paddock in every rotation. Herbage was sampled $>4 \mathrm{~cm}$ using Gardena hand shears (Accu 90, Gardena International GmbH, Ulm, Germany). Grab samples of herbage were collected at random locations along a W-shaped transect in the area due to be grazed next. The sample was then mixed, and two 70-g sub-samples were removed and separated into grass (sown PRG and weed grasses) and clover fractions, which were dried at $60^{\circ} \mathrm{C}$ for $48 \mathrm{~h}$ in a forced convection oven (Parsons Lane, Hope Valley, UK) to determine the DM proportions.

Herbage Chemical Composition. Once per paddock in each rotation, herbage representative of that selected by the cows (i.e., defoliating at the previous day's PostGSH) was manually collected with Gardena hand shears (as previously described) as described by Ganche et al. (2013). Samples were stored at $-18^{\circ} \mathrm{C}$. The frozen herbage sample was bowl-chopped (Muller, Type MKT 204 Special, Saabrücken, Germany), freezedried at $-50^{\circ} \mathrm{C}$ for $120 \mathrm{~h}$, and milled through a $1-\mathrm{mm}$ screen using a Cyclotech 1093 Sample Mill (Foss, DK3400 Hillerød, Denmark), and stored for analyses. The chemical composition of the harvested herbage was analyzed by wet chemistry for organic matter digestibility (OMD), CP, NDF, ADF, and ash concentrations. The OMD was estimated using the in vitro neutral detergent cellulase method (Fibertec Systems, Foss, 
Ballymount, Dublin, Ireland) described by Morgan et al. (1989). Crude protein concentration was determined using a N analyzer (FP-428, Leco Australia Pty Ltd., Castle Hill, New South Wales, Australia) based on the AOAC method 990-03 (AOAC, 1990). The NDF and ADF concentrations were determined using a fiber analyzer (Ankom Technology, Macedon, NY) based on the method described by Van Soest et al. (1991). Amylase and a sodium sulfite solution were used in the NDF concentration determination process. Ash concentration was estimated by burning a subsample in a muffle furnace at $500^{\circ} \mathrm{C}$ for $12 \mathrm{~h}$.

\section{Animal Measurements}

Milk Production. Cows were milked twice daily, at 0630 and $1530 \mathrm{~h}$, with an average of $3 \mathrm{~h}$ per day spent off the paddocks in the collecting yard and the milking parlor. Individual daily milk yield $(\mathrm{kg})$ was recorded at each milking (Dairymaster, Causeway, Co. Kerry, Ireland). Milk fat and protein concentrations were determined weekly from one successive evening and morning milking. The concentrations of these constituents were determined using Milkoscan 203 (Foss Electric DK-3400, Hillerød, Denmark). Milk solids yield (kg) was calculated as the yield of milk fat plus the yield of milk protein. Milk yield and milk solids yield per hectare were calculated by multiplying total lactation yields by the annual stocking rate for each treatment for each year as described by Patton et al. (2012).

$\boldsymbol{B} \boldsymbol{W}$ and $\boldsymbol{B} \boldsymbol{C S}$. Body weight and BCS were recorded fortnightly throughout the experiment. An electronic portable weighing scale with the Winweigh software package (Tru-test Limited, Auckland, New Zealand) was used to record BW. The BCS was scored by an experienced independent observer on a scale from 1 to 5 (where $1=$ emaciated, $5=$ extremely fat) with 0.25 increments (Lowman et al., 1973).

Herbage Intake Estimations. Individual DMI was estimated using the $n$-alkane technique (Mayes et al., 1986) as modified by Dillon and Stakelum, 1989) twice in 2013 (mid-May and mid-September), and 3 times in 2014 (mid-May, mid-July, and mid-September). All cows were dosed twice daily, after milking, for 12 consecutive days with a paper bullet (Carl Roth $\mathrm{GmbH}$, Karlsruhe, Germany) containing $500 \mathrm{mg}$ of dotriacontane $\left(\mathrm{C}_{32}-\right.$ alkane). From d 7 to 12 of dosing fecal samples were collected from each cow twice daily, before morning and evening milking, either in the paddock during the hour immediately before milking by observing the cows and collecting the sample when voided, or by rectal grab sampling after milking. Fecal samples were stored at $-18^{\circ} \mathrm{C}$ until the end of the collection period. Fecal samples from each cow were thawed and bulked together (12 $\mathrm{g}$ from each sample), dried at $60^{\circ} \mathrm{C}$ for $48 \mathrm{~h}$, milled through a 1-mm screen, and analyzed for alkane content.

In conjunction with the fecal collection, 2 herbage samples of approximately 15 individual grass snips were manually collected using Gardena hand shears (as described previously) mimicking the grazing defoliation pattern observed on previously grazed swards on d 6 to 11. The daily samples were stored at $-18^{\circ} \mathrm{C}$. Additionally, on the Cl250 and Cl150 treatments, a sub-sample of the herbage was manually separated into $100 \mathrm{~g}$ of grass and $100 \mathrm{~g}$ of clover and also frozen. The frozen herbage samples were bowl-chopped (Muller, Type MKT 204 Special, Saabrücken, Germany), freeze-dried at $-50^{\circ} \mathrm{C}$ for $72 \mathrm{~h}$, milled through a $1-\mathrm{mm}$ screen, and analyzed for alkane content.

The DMI was calculated as described by Hameleers and Mayes (1998). The PRG/clover ratio consumed was estimated from the concentrations of the odd-chain $n$-alkanes by using an iterative routine (Microsoft Excel Solver; Microsoft Corp., Redmond, WA) that minimizes the sum of squares of the discrepancy between the observed $n$-alkane fecal levels (expressed as a proportion of total alkane concentration and corrected for their recoveries; Dillon et al., 1995) and expected fecal $n$-alkane concentration calculated from the $n$-alkane concentration of the individual forage components.

$$
\begin{gathered}
\text { Minimize } \Sigma[(\text { calculated alkane proportion } \\
\left.- \text { actual proportion })^{2}\right] i \ldots \mathrm{n} ; \\
\text { calculated proportion alkane } \text { a }_{i}=\frac{p \times A_{i}+(1-p) \times B_{i}}{p \times A_{i}+(1-p) \times B_{t}} ; \\
\text { actual proportion alkane }{ }_{i}=\frac{F_{i}}{F_{t}} ;
\end{gathered}
$$

where $A_{i}, B_{i}, F_{i}=$ concentration of individual $n$-alkane ${ }_{i}$ in herbage $A$ and $B$ and feces $F ; p=$ proportion of the diet of herbage $A$ (set to be $0<p<1$ ); $B_{t}, F_{t}=$ sum of $n$-alkane concentrations used in the calculation $\left(\mathrm{C}_{27}\right.$, $\mathrm{C}_{29}, \mathrm{C}_{31}, \mathrm{C}_{33}, \mathrm{C}_{35}$ ) of herbage $B$ and feces $F$; and $i=$ odd chain $n$-alkanes involved in calculation $\left(\mathrm{C}_{27}, \mathrm{C}_{29}\right.$, $\left.\mathrm{C}_{31}, \mathrm{C}_{33}, \mathrm{C}_{35}\right)$.

Daily herbage intake $(\mathrm{kg}$ of $\mathrm{DM} / \mathrm{d}) I=$

$$
\frac{\left[\frac{F_{i}}{F_{j}}-1 \times\left(D_{j}+I_{c}\right)-I_{c}\right]}{\left\{\left[p \times A_{i}+(1-p) \times B_{i}\right]-\frac{F_{i}}{F_{j}} \times\left[p \times A_{j}+(1-p) \times B_{j}\right]\right\}},
$$


where $p=$ proportion of the diet of herbage $A ; I_{c}=$ intake concentration $\left(\mathrm{kg}\right.$ of DM/d); $D_{j}=$ dosed amount of $\mathrm{C}_{32} ; A_{i}, B_{i}, F_{i}=i$ is the concentration of $\mathrm{C}_{31}$ in herbage $A$ and $B$ and feces $F$; and $A_{j}, B_{j}, F_{j}=j$ is the concentration of $\mathrm{C}_{32}$ in herbages $A$ and $B$ and feces $F$.

\section{Statistical Analyses}

All data were analyzed using SAS 9.1.3 software (SAS Institute Inc., Cary, NC). Pregrazing HM, sward clover content, PreGSH, and PostGSH were analyzed using PROC MIXED, with year, treatment, rotation, and the associated interactions included in the model. Paddock was the experimental unit, with paddock introduced as the random factor and rotation the repeated measure. Data are presented as least squares means \pm standard error. Annual HM was analyzed using PROC GLM in SAS.

Daily milk yield, daily fat content, daily protein content, and daily milk solids yield were analyzed using PROC MIXED in SAS, with treatment, week, and the associated interactions included in the model. The individual cow was the experimental unit, and week was the repeated measure. Cumulative milk yield and milk solids yield were analyzed using PROC Mixed in SAS. Days in milk and block were included as covariates in the model.

Milk production variables were analyzed using the following model:

$$
\begin{aligned}
Y_{i j k l}=\mu & +C_{i}\left(S_{k}\right)+P_{j}+S_{k}+\mathrm{Wk}_{l}+P_{j} \times S_{k} \\
& +\mathrm{Wk}_{l} \times S_{k}+\mathrm{b} 1_{X i j k}+e_{i j k l},
\end{aligned}
$$

where $Y_{i j k l}$ is the response of the $i$ cow in the $k$ sward at $l$ week, $\mu$ is the mean, $C_{i}\left(S_{k}\right)$ the random effect of the cow within treatment, $P_{j}$ is the lactation ( $j=1$ to 5$), S_{k}$ is the treatment ( $k=$ grass or clover), $\mathrm{Wk}_{l}$ is the week of the experiment (1 to 39), $P_{j} \times S_{k}$ is the interaction of $P \times S, \mathrm{Wk}_{l} \times S_{k}$ is the interaction of $\mathrm{Wk} \times S, \mathrm{~b} 1_{X i j k}$ is the respective pre-experimental variable, and $e_{i j k l}$ is the residual error term.

Herbage DMI estimations were analyzed using PROC MIXED in SAS. Treatment, measurement period, and the associated interactions (treatment $\times$ measurement period) were included in the model. Individual cow was the experimental unit and measurement period (May, July, or September) was the repeated measure.

\section{RESULTS}

\section{Meteorological Data}

Meteorological data for the February to November period are shown in Table 3. Mean daily temperature for the experimental period in yr 1 and 2 were similar to the previous 10 -yr average $\left(10.6,11.2\right.$, and $10.9^{\circ} \mathrm{C}$, respectively). The 10-yr average rainfall was $827 \mathrm{~mm}$; in yr 1 rainfall was $74 \%(656 \mathrm{~mm})$ of the 10 -yr average, and in yr 2 rainfall was $120 \%$ (999 $\mathrm{mm}$ ) of the year average. Average soil temperature at $100-\mathrm{mm}$ soil depth in yr 1 and 2 (11.8 and $12.8^{\circ} \mathrm{C}$, respectively) experimental period was similar to the previous 10-yr average $\left(12.5^{\circ} \mathrm{C}\right)$.

\section{Sward Measurements}

Sward pregrazing HM, PreGSH, and PostGSH are shown in Table 4 (yr 1 and 2). Rotation had a significant $(P<0.05)$ effect on all herbage parameters measured in both years of the study (Table 4).

No effect of treatment $(P>0.07)$ was observed on PreGSH $(10.1 \mathrm{~cm} \pm 0.06)$. A significant treatment by rotation interaction $(P<0.001)$ was observed on PreGSH in yr 1 and 2 (Table 4 ). In yr 1 , the Gr250 treatment had the greatest PreGSH in rotations 2 and

Table 3. Metrological data during the experimental period (February to November) in yr 1 (2013) and yr 2 (2014) compared with the previous

\begin{tabular}{|c|c|c|c|c|c|c|c|c|c|c|c|}
\hline Month & February & March & April & May & June & July & August & September & October & November & Average $^{1}$ \\
\hline 2013 & 4.9 & 4.4 & 7.7 & 10.3 & 13.3 & 17.7 & 15.8 & 13.9 & 12.0 & 6.0 & 10.6 \\
\hline 2014 & 5.5 & 7.0 & 9.6 & 11.8 & 14.6 & 16.4 & 14.0 & 14.0 & 11.4 & 7.5 & 11.2 \\
\hline \multicolumn{12}{|c|}{ Rainfall (mm/mo) } \\
\hline 2013 & 46 & 85 & 71 & 64 & 35 & 61 & 52 & 38 & 150 & 54 & 656 \\
\hline 2014 & 223 & 88 & 76 & 72 & 92 & 59 & 65 & 23 & 154 & 148 & 999 \\
\hline \multicolumn{12}{|c|}{ Soil temperature $\left({ }^{\circ} \mathrm{C}>100 \mathrm{~mm}\right)$} \\
\hline 2013 & 4.9 & 5.0 & 8.2 & 11.3 & 13.8 & 21.1 & 18.0 & 15.7 & 13.3 & 7.0 & 11.8 \\
\hline 2014 & 5.1 & 7.3 & 10.9 & 14.1 & 18.2 & 19.0 & 17.0 & 15.8 & 12.4 & 8.1 & 12.8 \\
\hline 2003 to 2012 & 5.4 & 7.4 & 9.6 & 13.1 & 16.9 & 17.2 & 17.4 & 15.0 & 10.7 & 12.5 & 12.5 \\
\hline
\end{tabular}
10-yr average (2003-2012)

${ }^{1}$ Average $=$ mean value February to November. 
EGAN ET AL.

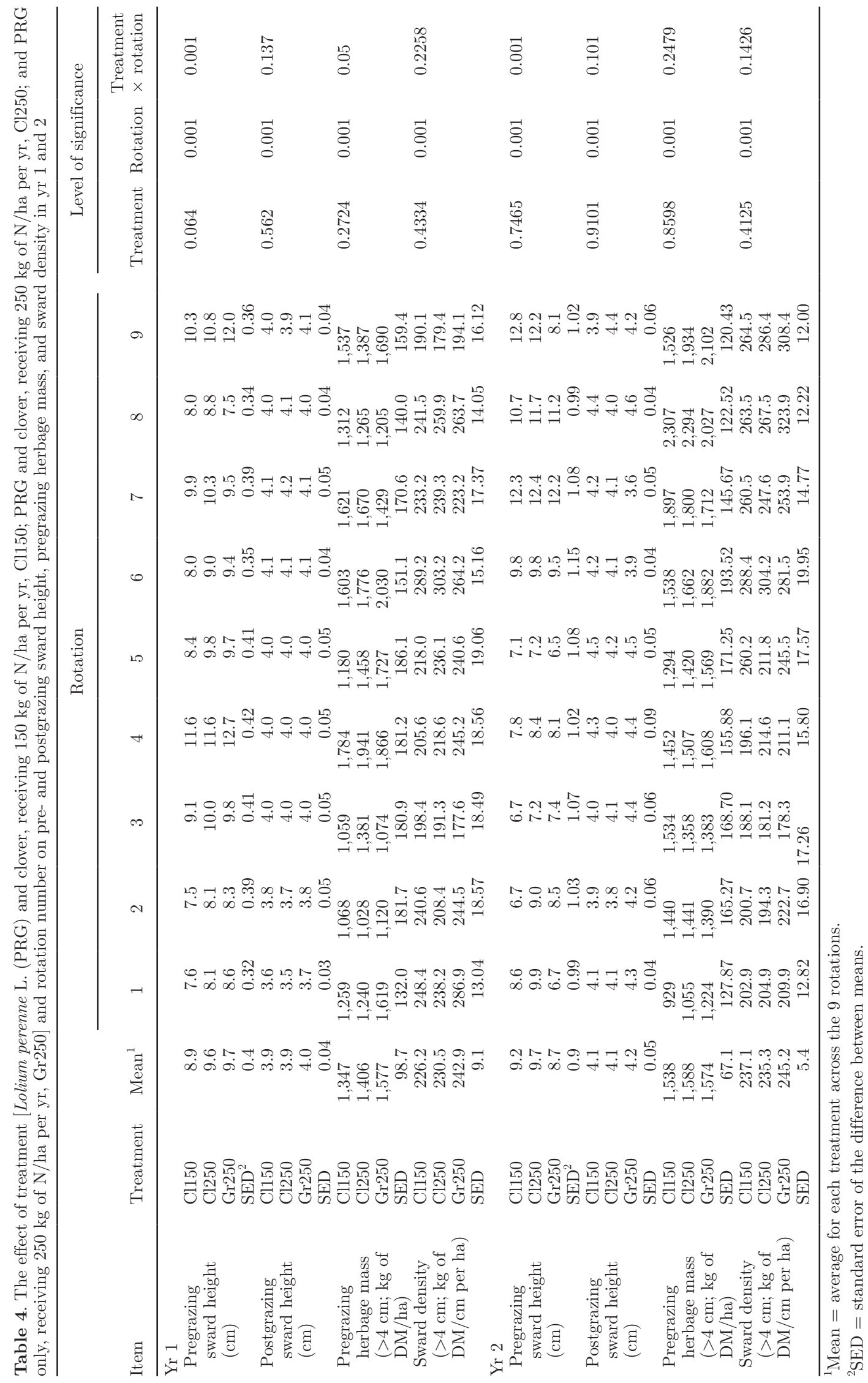


9 compared with both clover treatments. The $\mathrm{Cl} 250$ treatment had the lowest PreGSH in yr 1 in rotation 6 and had the greatest PreGSH in rotations 5 and 8. Average PostGSH was 3.94 and $4.13 \mathrm{~cm} \pm 0.045$ in yr 1 and 2 , respectively $(P<0.001)$. There was no effect of treatment $(P=0.11)$ on PostGSH $(4.0 \mathrm{~cm} \pm 0.02)$.

A significant treatment by rotation interaction effect $(P<0.05)$ was observed on pregrazing HM in yr 1 . The Gr250 treatment had the greatest pregrazing HM in rotation 1 compared with the $\mathrm{Cl} 250$ and Cl150 treatments. In rotation 5 and 6 , the Gr250 treatment had a greater pregrazing HM than the Cl150 treatment with the Cl250 treatment intermediate to both. All swards had a similar pregrazing $\mathrm{HM}$ in rotations $2,3,4,7,8$, and 9 .

Increasing the level of $\mathrm{N}$ fertilizer had a significant effect $(P<0.001)$ on sward clover content (Table 5$)$. The Cl150 treatment had a greater clover content compared with the $\mathrm{Cl} 250$ treatment (266 and $225 \mathrm{~g} / \mathrm{kg}$ of $\mathrm{DM} \pm$ 7.3 , respectively). Sward clover content was greater in yr 2 compared with yr $1(P<0.05$; data not shown; 259 and $233 \mathrm{~g} / \mathrm{kg}$ of $\mathrm{DM} \pm 7.2$, respectively). Rotation had an effect on sward clover content $(P<0.001$; Figure 1 ). Sward clover content was least in rotation 1 (February and March), 84.9 and $72.3 \mathrm{~g} / \mathrm{kg}$ of $\mathrm{DM} \pm 21.8$ for both the $\mathrm{Cl} 150$ and $\mathrm{Cl} 250$ treatments, respectively, and greatest in rotation 7 (July/August) $(431 \mathrm{~g} / \mathrm{kg}$ of DM $\pm 20.4)$ on $\mathrm{Cl} 150$ and in rotation $8(348 \mathrm{~g} / \mathrm{kg}$ of $\mathrm{DM} \pm$ 20.4) on Cl250.

Treatment did not have a significant effect $(P>0.05)$ on total cumulative herbage production $(13,039,14,175$, and 13,288 $\mathrm{kg}$ of DM/ha \pm 420.1, on Cl150, Cl250, and

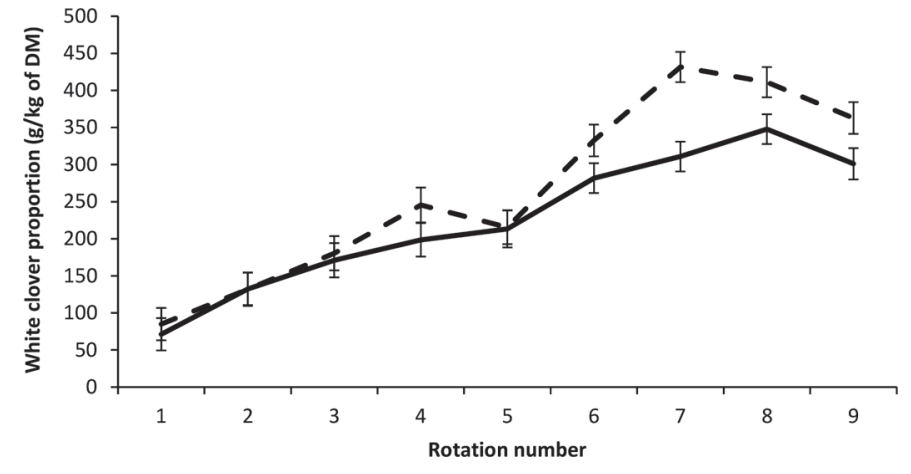

Figure 1. Least squares means of white clover proportion for a Lolium perenne L. (PRG) and clover sward, receiving $150 \mathrm{~kg}$ of N/ha per yr (broken black line); and a PRG and clover sward, receiving 250 $\mathrm{kg}$ of $\mathrm{N} /$ ha per yr (solid black line) in the pregrazing herbage mass $(>4$ $\mathrm{cm}$ ). Data are means for 2013 and 2014. Error bars represent standard error of the difference between means.

Gr250, respectively). Cumulative herbage production was, however, lower $(P<0.01)$ in yr $1(12,150 \mathrm{~kg}$ of $\mathrm{DM} / \mathrm{ha} \pm 390.4)$ than in yr $2(14,865 \mathrm{~kg}$ of $\mathrm{DM} / \mathrm{ha} \pm$ 304.2; data not shown).

Treatment did not affect $(P>0.05)$ herbage OMD, $\mathrm{CP}$, or ADF content (Table 6). Treatment had a significant effect $(P<0.001)$ on NDF concentration. The $\mathrm{Cl} 250$ and Cl150 treatments had a lower NDF concentration than the Gr250 treatment (338.4 and $358.3 \mathrm{~g} /$ $\mathrm{kg}$ of $\mathrm{DM} \pm 3.8$, respectively). Treatment had a significant effect $(P<0.05)$ on ash concentration, which was greater in the Cl150 treatment than the Cl250 and Gr250 treatments.

Table 5. The effect of treatment [Lolium perenne L. (PRG) and clover, receiving $150 \mathrm{~kg}$ of N/ha per yr, Cl150; PRG and clover, receiving 250 $\mathrm{kg}$ of N/ha per yr, Cl250; and PRG only, receiving $250 \mathrm{~kg}$ of N/ha per yr, Gr250] on milk production and milk composition, BW and BCS, silage fed, and sward clover content during the experimental period (February to November in yr 1 and 2)

\begin{tabular}{|c|c|c|c|c|c|c|c|}
\hline Item & \multicolumn{3}{|c|}{ Treatment } & $\mathrm{SED}^{1}$ & \multicolumn{3}{|c|}{ Level of significance } \\
\hline Clover content (g/kg of DM) & $266^{\mathrm{a}}$ & $225^{\mathrm{b}}$ & - & 7.3 & 0.001 & 0.001 & - \\
\hline $\begin{array}{l}\text { Cumulative herbage production } \\
\text { (kg of DM/ha) }\end{array}$ & 13,039 & 14,175 & 13,288 & 420.1 & 0.13 & - & - \\
\hline Milk yield (kg/cow per $\mathrm{d})$ & $21.8^{\mathrm{ab}}$ & $22.1^{\mathrm{a}}$ & $20.9^{\mathrm{b}}$ & 0.33 & 0.05 & 0.001 & 0.001 \\
\hline Milk fat $(\mathrm{g} / \mathrm{kg})$ & $46.2^{\mathrm{a}}$ & $45.0^{\mathrm{b}}$ & $44.6^{\mathrm{b}}$ & 0.37 & 0.01 & 0.001 & 0.001 \\
\hline Cumulative $^{2}$ milk yield $(\mathrm{kg} / \mathrm{cow})$ & 6,166 & 6,229 & 5,984 & 136.5 & 0.06 & - & - \\
\hline Cumulative milk solids yield ( $\mathrm{kg} / \mathrm{cow})$ & 499 & 497 & 464 & 12.3 & 0.05 & - & - \\
\hline $\mathrm{BW}(\mathrm{kg} / \mathrm{cow})$ & 548 & 549 & 538 & 5.0 & 0.23 & 0.001 & 0.001 \\
\hline $\mathrm{BCS}(1-5)$ & $3.13^{\mathrm{a}}$ & $3.16^{\mathrm{a}}$ & $3.05^{\mathrm{b}}$ & 0.015 & 0.001 & 0.001 & 0.001 \\
\hline Cumulative milk yield (kg/ha) & 16,896 & 17,070 & 16,152 & 374.2 & 0.06 & - & - \\
\hline Cumulative milk solids yield $(\mathrm{kg} / \mathrm{ha})$ & 1,367 & 1,361 & 1,276 & 31.4 & 0.05 & - & - \\
\hline Silage fed (kg of DM/cow) & $664^{\mathrm{a}}$ & $584^{\mathrm{b}}$ & $571^{\mathrm{b}}$ & 13.22 & 0.05 & - & - \\
\hline
\end{tabular}

\footnotetext{
$\overline{\mathrm{a}, \mathrm{b}}$ Values in the same row not sharing a common superscript are significantly different.

${ }^{1} \mathrm{SED}=$ standard error of the difference between means.

${ }^{2}$ Cumulative $=$ total for experimental period (February to November 2013 and 2014).
} 
EGAN ET AL.

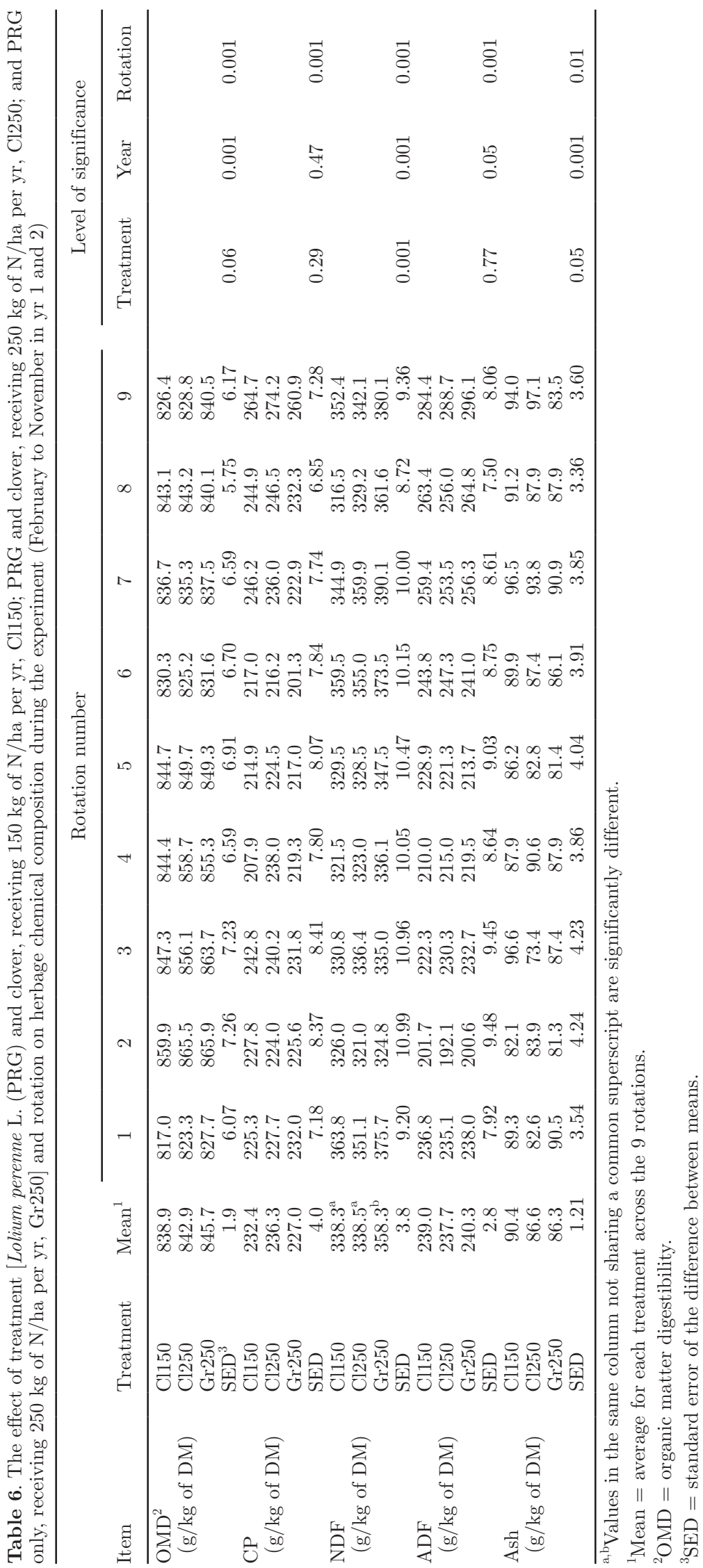




\section{Animal Production}

Milk Yield, Milk Solids Yield, BW, and BCS. A significant treatment by week interaction $(P<0.05)$ was observed on daily milk solids yield (Figure 2). All treatments had similar daily milk solids yield for experimental wk 1 to 14, and in wk 16, 17, 30, and 41 . In wk 19, 23, 25, 37, and 40, cows grazing the Cl250 treatment had greater daily milk solids yield compared with cows grazing the Gr250 treatment. In wk 34, the cows grazing the Cl150 treatment had greater daily milk solids yield compared with the cows grazing the Gr250 treatment. In all other weeks, the cows grazing the $\mathrm{Cl} 250$ and Cl150 treatments had greater daily milk solids yield than the cows grazing the Gr250 treatment. This resulted in a significant difference $(P<0.05)$ in cumulative milk solids yield per cow and per hectare. Cows grazing the Cl150 and Cl250 treatments had greater milk solids yield per cow (499 and $497 \mathrm{~kg} / \mathrm{cow}$ \pm 12.8 , respectively) and milk solids yield per hectare (1,367 and $1,361 \mathrm{~kg} / \mathrm{ha} \pm 31.4$, respectively) compared with the Gr250 treatment $(466 \mathrm{~kg} / \mathrm{cow} \pm 11.5$ and $1,276 \mathrm{~kg} / \mathrm{ha} \pm 31.4$, respectively).

A significant treatment by week interaction $(P<$ 0.001) was observed on daily milk yield (Figure 3 ). All 3 treatments had similar milk yield from wk 1 to 8 and in wk 30, 40, and 41 of the experimental period. In wk $9,13,15,18,1920,23$, and 37 , daily milk yield was greater on the Cl250 treatment than on the Gr250 treatment. In all other weeks milk yield was similar on $\mathrm{Cl} 250$ and Cl150, and greater than Gr250. Although not significantly different, the Cl150 and Cl250 treat- ments tended $(P=0.06)$ to have greater cumulative milk yield per cow and per hectare compared with the Gr250 treatment.

A significant treatment by week of experiment interaction $(P<0.001)$ was observed on daily milk fat concentration (Table 5). Milk fat concentration was higher for cows on the Cl150 treatment than for cows on the $\mathrm{Cl} 250$ and Gr250 treatments in wk 28 and 32 to 35 (data not shown).

Daily milk yield, milk solids yield, fat concentration, and protein concentration were greater $(P<0.001)$ in yr 2 than in yr 1 (data not shown). Because different cows were used in each year, and there were differences in weather conditions and pregrazing HM, the year effect was expected and is therefore not discussed any further in this paper.

No significant effect of treatment was observed on BW (Table 5). However, a significant effect of treatment was observed on BCS; the Gr250 cows had a significantly lower BCS compared with both the Cl250 and Cl150 treatments.

Silage Fed During the Experiment. The cows in the Cl150 treatment were fed a greater quantity of silage than the cows in the Cl250 and Gr250 treatments $(P<0.05$; Table 5$)$. Year also had a significant effect (data not shown; $P<0.001$ ) with more silage fed per cow in yr 1 compared with yr 2 (917 and $295 \mathrm{~kg}$ of DM/ cow \pm 10.8 , respectively).

Herbage DMI. A significant treatment by measurement period interaction $(P<0.001)$ was observed for total DMI (Table 7). In May, the cows on the Cl250 treatment had the greatest DMI. In July, the cows

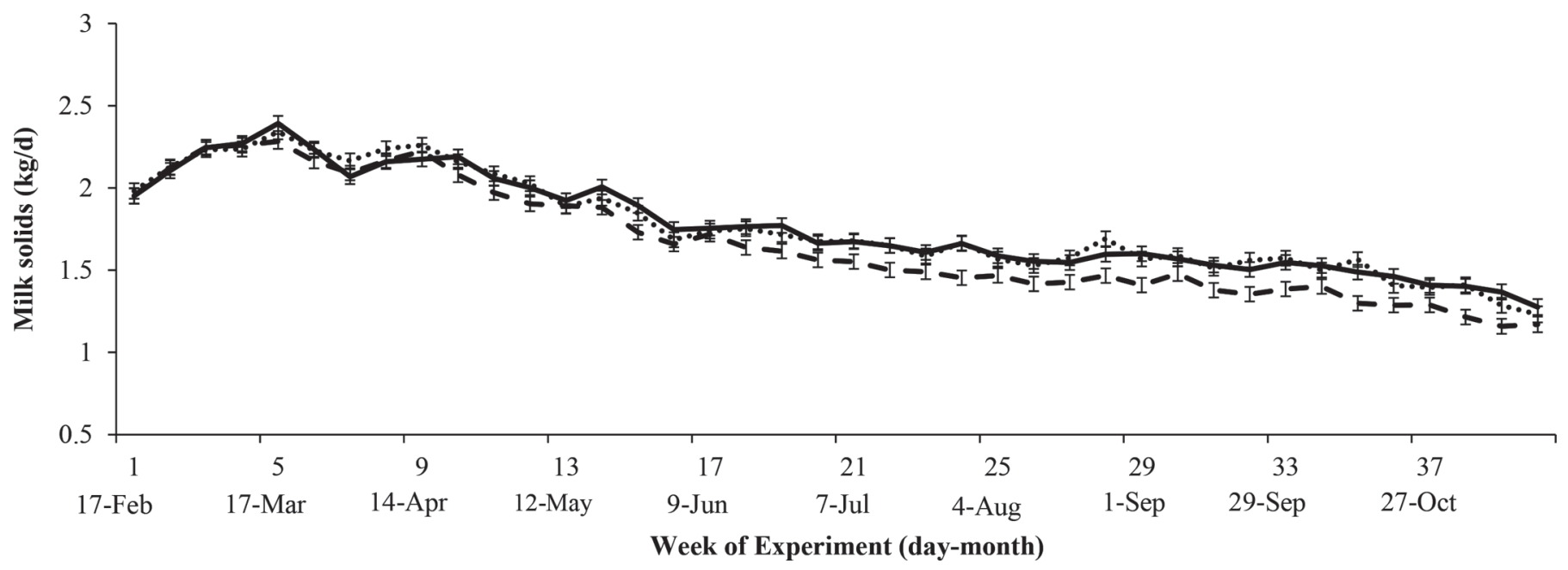

Figure 2. Least squares means of the effect of treatment [Lolium perenne L. (PRG) and clover, receiving $150 \mathrm{~kg}$ of N/ha per yr, dotted black line; PRG and clover, receiving $250 \mathrm{~kg}$ of N/ha per yr, solid black line; and PRG-only sward, receiving $250 \mathrm{~kg}$ of N/ha per yr, broken black line] on dairy cow daily milk solids. Data are presented as a mean of 2 yr (February to November 2013 and 2014). Error bars represent standard error of the difference between means. 
Table 7. The effect of treatment [Lolium perenne L. (PRG) and clover, receiving $150 \mathrm{~kg}$ of N/ha per yr, Cl150; PRG and clover, receiving 250 $\mathrm{kg}$ of N/ha per yr, Cl250; and PRG only, receiving $250 \mathrm{~kg}$ of N/ha per yr, Gr250] and measurement period (May, July, and September) on total DMI, perennial ryegrass DMI, and white clover DMI (LSM) in yr 1 (2013) and yr 2 (2014)

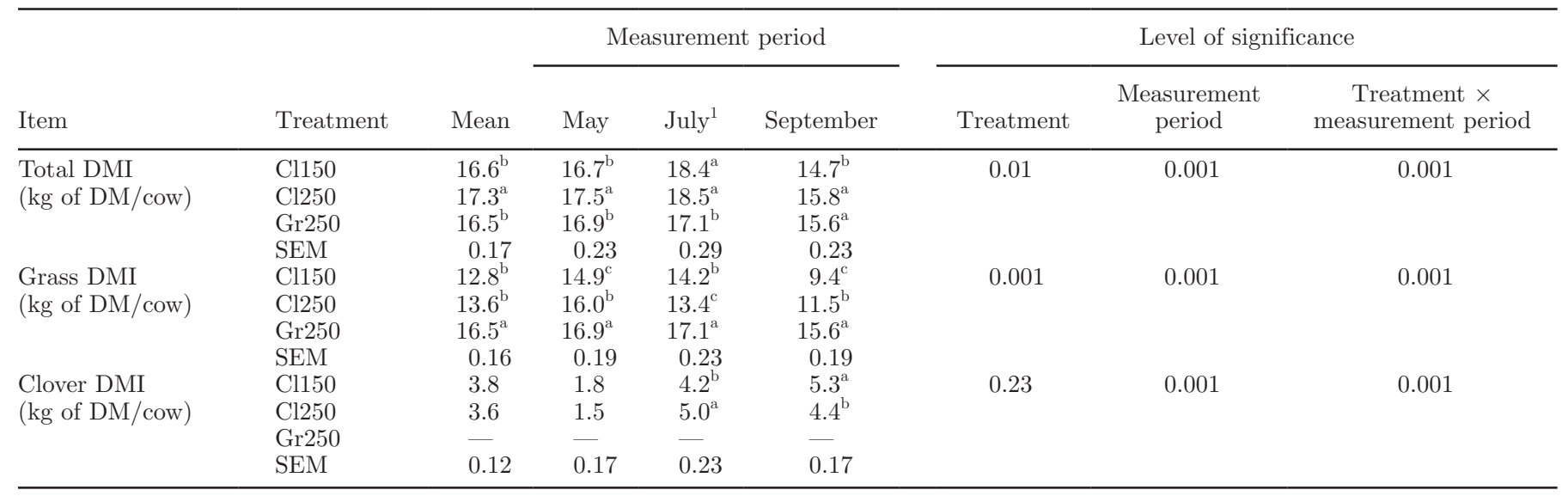

${ }^{\mathrm{a}-\mathrm{c}}$ Values in the same column not sharing a common superscript are significantly different.

${ }^{1}$ July only represents samples from 2014.

on the $\mathrm{Cl} 250$ and Cl150 treatments had similar DMI, which was greater than the cows on treatment Gr250, whereas in September, the cows on treatment Cl150 had the lowest DMI and the cows on treatments $\mathrm{Cl} 250$ and Gr250 had similar DMI.

In September, the cows on the Cl150 treatment had a greater clover DMI compared with the cows on the Cl250 treatment. In the Cl250 and Cl150 treatments, clover made up 80 and $110 \mathrm{~g} / \mathrm{kg}$ of DM, respectively, of the total DMI in May; 270 and $230 \mathrm{~g} / \mathrm{kg}$ of DM, respectively, in July; and 280 and $360 \mathrm{~g} / \mathrm{kg}$ of DM, respectively, in September.

\section{DISCUSSION}

\section{Sward Productivity}

Total annual herbage DM production was not significantly affected by the inclusion of clover into a PRG sward in the current experiment, similar to Enriquez-

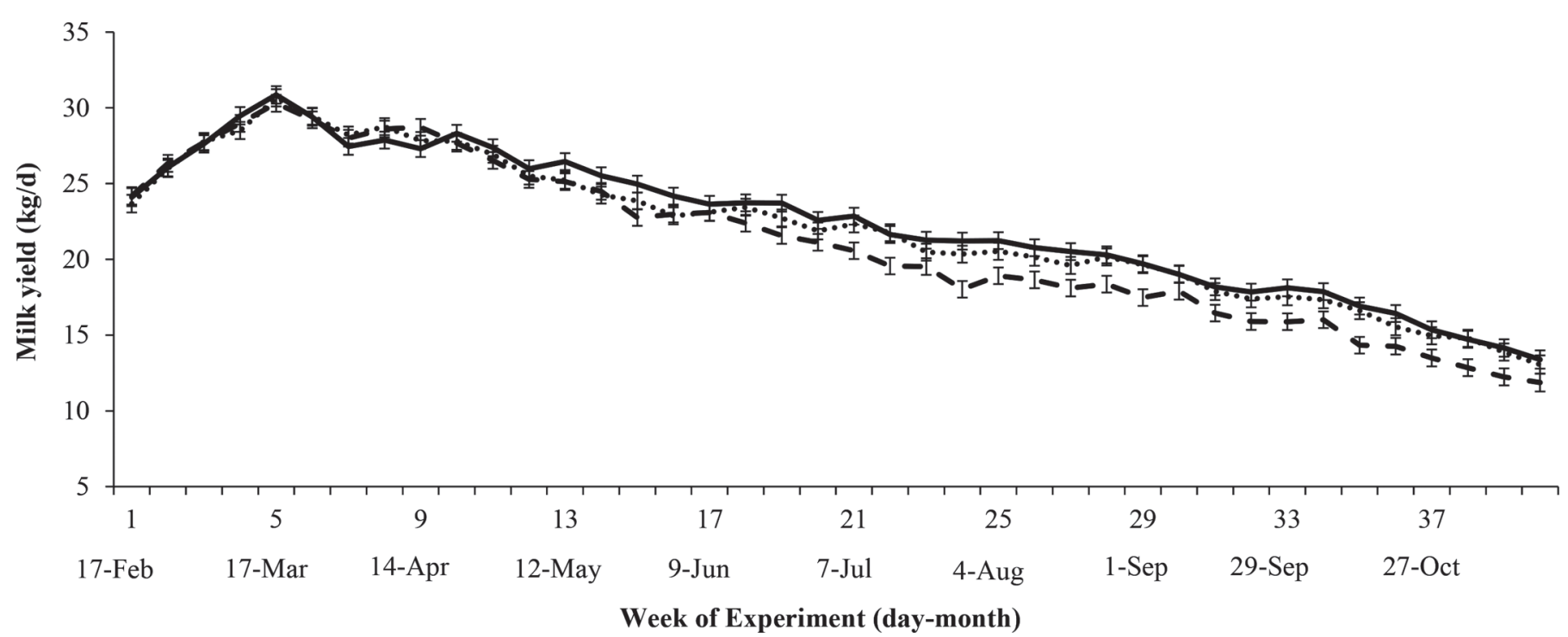

Figure 3. Least squares means of the effect of treatment [Lolium perenne L. (PRG) and clover, receiving $150 \mathrm{~kg}$ of N/ha per yr, dotted black line; PRG and clover, receiving $250 \mathrm{~kg}$ of N/ha per yr, solid black line; and PRG-only sward, receiving $250 \mathrm{~kg}$ of N/ha per yr, broken black line] on dairy cow daily milk yield. Data are presented as a mean of 2 yr (February to November 2013 and 2014). Error bars represent standard error of the difference between means. 
Hidalgo et al. (2014a) and Egan et al. (2017). However, numerically the $\mathrm{Cl} 250$ swards produced approximately an extra 1,000 $\mathrm{kg}$ of $\mathrm{DM} / \mathrm{ha}$ compared with the Cl150 and Gr250 swards. Within a farm system similar to the current study, this extra $1,000 \mathrm{~kg}$ of $\mathrm{DM} / \mathrm{ha}$ is a valuable asset and provides additional forage either for grazing or for silage conservation. Ledgard et al. (2001) and Humphreys et al. (2008) reported that a PRG/ clover sward with no $\mathrm{N}$ fertilizer application produced $80 \%$ of the herbage of a PRG-only sward receiving high $\mathrm{N}$ fertilizer $(>240 \mathrm{~kg}$ of N/ha) application. Similar to Enriquez-Hidalgo et al. (2016), in the experiment reported here PRG/clover swards receiving $150 \mathrm{~kg}$ of N/ ha (Cl150) produced similar total herbage DM yield to the PRG-only swards receiving $250 \mathrm{~kg}$ of N/ha (Gr250). This offers a considerable potential saving to the farmer in terms of $\mathrm{N}$ fertilizer application in a pasture-based system.

Unlike previous studies which have reported reduced pregrazing $\mathrm{HM}$ in PRG/clover swards compared with grass-only sward (Schils et al., 2000; Ribeiro Filho et al., 2005), average pregrazing HM in the current study was similar across treatments. The studies cited above used $<70 \mathrm{~kg}$ of $\mathrm{N} / \mathrm{ha}$ compared with 150 or $250 \mathrm{~kg}$ of $\mathrm{N} / \mathrm{ha}$ in the current experiment, which could have accounted for the difference in pregrazing HM. Pregrazing HM in the current study did, however, vary between treatments across the grazing season. In the current study, the $\mathrm{Cl} 250$ and Cl150 treatments had $300 \mathrm{~kg}$ of DM/ha less pregrazing HM than the Gr250 swards in rotation 1 (February/March), reflecting the lower overwinter clover growth rate (Frame and Newbould, 1986). Perennial ryegrass over winter growth rate has been previously reported to be in the range of 6.9 to $9.4 \mathrm{~kg}$ of $\mathrm{DM} / \mathrm{d}$ (Lawrence, 2015) on simulated grazed swards at Teagasc Moorepark. In the current study, average farm cover (HM present on each sward; $\mathrm{kg}$ of $\mathrm{DM} / \mathrm{ha}$ ) at the end of January was 395, 504, and $784 \mathrm{~kg}$ of DM/ha for the Cl150, Cl250, and Gr250 treatments, respectively. The difference in farm cover was a result of the difference in over winter growth; the Cl150 and Cl250 swards lost on average 4.4 and $1 \mathrm{~kg}$ of DM/ha per d, respectively, in December and January, whereas the Gr250 swards grew on average $6.8 \mathrm{~kg}$ of DM/ha per $\mathrm{d}$ over the same period. The minimum and optimal temperatures for clover growth are higher than those for PRG (Davies, 1992), which can account for the lower growth in winter and early spring on the PRG/clover swards. The low farm cover on the Cl150 treatment resulted in an extra 80 and $93 \mathrm{~kg}$ of DM silage being fed per cow in the rotation 1 compared with the $\mathrm{C} 1250$ and Gr250 treatments, respectively. The difference in HM between treatments had disappeared by the beginning of rotation 2 .
Due to lower growth rates on PRG/clover swards in spring compared with PRG swards (Frame and Newbould, 1986), $\mathrm{N}$ fertilizer can be applied in that period to counteract the reduction in clover spring growth by boosting PRG growth (Humphreys et al., 2008). Laidlaw (1980), Humphreys et al. (2009), and EnriquezHidalgo et al. (2016) reported that the application of $<90 \mathrm{~kg}$ of $\mathrm{N} /$ ha per yr can increase spring herbage production in PRG/clover swards without affecting annual sward clover content in temperate grassland systems in northwest Europe. Later and repeated applications of $\mathrm{N}$ fertilizer to $\mathrm{PRG}$ /clover swards can be detrimental to sward clover content (Frame and Boyd, 1987a). Average sward clover content was $266 \mathrm{~g} / \mathrm{kg}$ of DM for the Cl150 treatment, similar to Frame and Boyd (1987a); and $225 \mathrm{~g} / \mathrm{kg}$ of DM for the Cl250 treatment, which is similar to that reported by Enriquez-Hidalgo et al. (2016) and higher than Frame and Boyd (1987a), Harris et al. (1996), and Ledgard et al. (2001) at that $\mathrm{N}$ fertilizer application rate in northwest Europe and New Zealand. The difference in $\mathrm{N}$ fertilizer applications between Cl150 and Cl250 resulted in a $41 \mathrm{~g} / \mathrm{kg}$ of DM reduction in sward clover content. This is much smaller than that reported by Frame and Boyd (1987a) who found a $169 \mathrm{~g} / \mathrm{kg}$ of DM difference at $\mathrm{N}$ fertilizer application levels similar to those in this experiment. The frequent grazing (9 grazing rotations between February and November) implemented in this study combined with relatively low pregrazing HM, especially in rotations 1 to 3 , and the consistently low PostGSH $(\sim 4 \mathrm{~cm})$ likely minimized the shading of clover by PRG (Nassiri and Elgersma, 1998) and increased sward clover content in subsequent rotations (Hoogendoorn et al., 1992).

Sward clover content was 24 to $28 \mathrm{~g} / \mathrm{kg}$ of DM higher in yr 2 compared with yr 1, regardless of $\mathrm{N}$ fertilizer application rate. Similarly, in southern Asia, Yu et al. (2008) found an increase in sward clover content from the first year post sowing to the second year. Nevertheless, as only 2 yr of measurements were undertaken in the current experiment, it is unclear if the clover will continue to increase in subsequent years, or if the clover gradually disappears after the first 2 seasons as previously reported by Wilman and Hollington (1985) and Frame and Boyd (1987b). Williams et al. (2003) observed that sward clover content can be maintained for 8 to $10 \mathrm{yr}$ under moderate levels of $\mathrm{N}$ fertilizer in intensively managed swards.

\section{Herbage Chemical Composition}

The herbage grown on all treatments in the current study was generally of high quality. Clover inclusion did not increase OMD compared with the Gr250 sward, similar to Humphreys et al. (2009) and Enriquez-Hi- 
dalgo et al. (2014a). It has previously been reported by Leach et al. (2000) and Riberio Filho et al. (2003) that herbage digestibility is greater on PRG/clover swards compared with PRG-only swards at low $\mathrm{N}$ input levels. Clover has a greater digestibility than PRG (Thomson, 1984), and therefore it would have been expected to enhance the overall herbage digestibility in the current study. The high N fertilizer application (Whitehead, 1995; Salaün et al., 1999) and low pregrazing HM (Beecher et al., 2015) applied in this study may have resulted in the similar OMD.

When grown at lower $\mathrm{N}$ fertilizer rates, clover has greater CP concentration than PRG (Rattray and Joyce, 1974; Thomson, 1984; Thomson et al., 1985). In the current study, all treatments had similar CP concentrations, similar to Enriquez-Hidalgo et al. (2014a). Reid (1970) reported that the effect of clover in PRG/ clover swards on $\mathrm{CP}$ concentration is reduced with increasing levels of $\mathrm{N}$ fertilizer application. Increasing $\mathrm{N}$ fertilizer application can reduce clover $\mathrm{N}$ fixation compared with swards receiving lower levels of $\mathrm{N}$ fertilizer. This can result in a reduction of the effect of clover on sward CP concentration (Reid and Castle, 1965).

The NDF concentration of PRG is usually greater than that of legumes (Thomson, 1984; Van Soest, 1994). In the current study, although small, herbage NDF concentration was $20 \mathrm{~g} / \mathrm{kg}$ lower in the Cl150 and Cl250 treatments compared with the Gr250 treatment, similar to Buxton (1996) and Harris et al. (1997a). Although not measured in the current study, the difference in NDF concentration between PRG and legumes could potentially be due to differences in leaf and stem proportion. Stem has a higher concentration of cell walls than leaf and is therefore less digestible (Buxton, 1996), and clover has a lower proportion of stem than PRG (Ulyatt et al., 1977; Buxton, 1996), which could have accounted for the differenced observed in the current study.

\section{Animal Performance}

In the current study, daily milk and milk solids yields were increased as a result of the inclusion of clover in a PRG sward over 2 full lactations. Thomson et al. (1985) and Harris et al. (1998) found similar results; however, this was in short-term component studies. Other studies examining the inclusion of clover in PRG swards over full grazing seasons similar to the current study (Schils et al., 2000; Humphreys et al., 2009; Enriquez-Hidalgo et al., 2014a; Egan et al., 2017) have found varying milk production responses. Schils et al. (2000) reported an increase in milk production per cow on PRG/clover swards compared with PRG only. Humphreys et al. (2009) and Enriquez-Hidalgo et al. (2014a) reported no animal production benefits with PRG/clover swards compared with PRG only. Previous studies (Schils et al., 2000), examining the inclusion of clover in grazing systems, reduced stocking rate as a result of reduced $\mathrm{N}$ fertilizer, which reduced milk production per hectare by 25\%. Egan et al. (2017) reported a $9 \%$ increase in milk production with the inclusion of clover in a PRG sward at a common stocking rate. In the experiment reported here, where the stocking rate was the same across the grass-only and grass-clover treatments, incorporating clover in to the PRG sward increased milk solids yield by $91(7.1 \%)$ and $85(6.6 \%)$ $\mathrm{kg} / \mathrm{ha}$ from the Cl150 and Cl250 treatments, compared with the Gr250 treatment. This increase in milk solids yield per hectare is financially important to dairy farmers. Greater milk production with the inclusion of clover in the sward is usually due to a combination of higher voluntary DMI and the increased nutritive value of the diet (Clark and Harris, 1996; Harris et al., 1997a, 1998). The largest difference in milk production in the current study occurred in the second half of the grazing season (June onward), similar to Schils et al. (2000) and Woodward et al. (2001). This occurred at the time when the difference in DMI between treatments was greatest. The DMI was $8 \%$ greater on the $\mathrm{Cl} 250$ and Cl150 treatments compared with the Gr250 treatment in July. Andrews et al. (2007) reported that a sward clover content $>200 \mathrm{~g} / \mathrm{kg}$ of DM is required to observe an animal production benefit from incorporating clover in the sward. In the current study, although Cl150 had a greater sward clover content than Cl250 (290 and 270 g clover $/ \mathrm{kg}$ of DM, respectively), animals on the Cl250 and Cl150 treatment selected a diet containing 270 and $230 \mathrm{~g}$ of clover $/ \mathrm{kg}$ of $\mathrm{DM}$, respectively, in July. The large content of clover in the swards likely accounted for the increase in DMI (Harris et al., 1997b, 1998).

Voluntary DMI of forages can vary depending on several factors, including the forage's resistance to breakdown (Minson, 1990). Particles must be reduced to a size $<1 \mathrm{~mm}$ before they can readily flow from the rumen (Moseley and Jones, 1984); chewing during eating and ruminating are the most important way in which forage particles are reduced in size (Minson, 1990; Wilson and Kennedy, 1996). Wilson and Kennedy (1996) reported that a shorter period of ruminating is required for clover swards to reach a particle size small enough to pass through the rumen. When available, clover is eaten in greater quantities then grasses because it has a lower resistance to breakdown during eating and ruminating (Minson, 1990). The lower resistance to breakdown of clover over PRG (Minson, 1990) can be attributed to a lower NDF concentration (Dewhurst et al., 2003; Enriquez-Hidalgo et al., 2014b; Egan et al., 2017), which was observed in the current study. Van 
Soest et al. (1991) and Van Soest (1994) reported that NDF is more closely related to the daily ruminating time and DMI than any other chemical fraction.

The inclusion of clover in PRG swards can reduce milk fat concentration (Thomson et al., 1985; Harris et al., 1997b) due to a faster rate of passage of feed through the rumen (Ulyatt, 1981; Thomson et al., 1985) and lower diet structural carbohydrate content (Davies, 1992). In the study reported here, milk fat concentration was not different on $\mathrm{Cl} 250$ and Gr250, similar to Riberio Filho et al. (2003), Ribeiro Filho et al. (2005), and Enriquez-Hidalgo et al. (2014a). There was no difference in milk protein concentration between treatments in the current study, similar to Phillips (1998), Leach et al. (2000), Enriquez-Hidalgo et al. (2014a), and Egan et al. (2017). This is not uncommon in a PRG/clover sward. The CP concentration of all swards was similar $(232 \mathrm{~g} / \mathrm{kg}$ of $\mathrm{DM})$, and additionally, the herbage $\mathrm{CP}$ concentration in all treatments exceeded the $\mathrm{CP}$ requirements of dairy cows (150 to $180 \mathrm{~g} / \mathrm{kg}$ of DM) for milk production (NRC, 2001). The inclusion of clover in PRG swards can result in increased levels of $\mathrm{N}$ concentration of the total herbage, because of the higher digestible protein in clover compared with PRG (Thomson, 1984). In the current study, however, no difference was observed in herbage CP content. In general, the diet of grazing ruminants contains an excess of $\mathrm{CP}$ due to an inefficient utilization of $\mathrm{N}$ present in the diet (Macduff et al., 1990; Ledgard et al., 2009), which when excreted can result in $\mathrm{N}$ loss to the environment. Contrasting findings have been made in terms of $\mathrm{N}$ losses from mixed PRG/clover swards compared with PRG $\mathrm{N}$ fertilizer swards from previous research, mainly due to a reduction in $\mathrm{N}$ fertilizer application on the mixed PRG/clover swards (Macduff et al., 1990; Ledgard et al., 2009). Where direct comparisons have been made, mixed clover swards and PRG swards with similar N inputs leached similar quantities of $\mathrm{NO}_{3}{ }^{-}$(Cuttle et al., 1992). The experiment presented here found similar herbage production on all 3 treatments indicating potential to reduce $\mathrm{N}$ fertilizer application to $150 \mathrm{~kg}$ of $\mathrm{N} /$ ha on grass-clover swards, even at a stocking rate of 2.74 cows/ha.

\section{CONCLUSIONS}

The frequent and tight grazing management used in the current study maintained a sward clover content of $>225 \mathrm{~g} / \mathrm{kg}$ of DM. Applying an extra $100 \mathrm{~kg}$ of N fertilizer/ha reduced sward clover content by $40 \mathrm{~g} / \mathrm{kg}$. Including clover in PRG swards receiving $250 \mathrm{~kg}$ of N/ ha per year increased herbage production by $1,000 \mathrm{~kg}$ of $\mathrm{DM} /$ ha. The PRG/clover treatment receiving $150 \mathrm{~kg}$ of $\mathrm{N} /$ ha had similar herbage production to the PRG-only treatment receiving $250 \mathrm{~kg}$ of $\mathrm{N} /$ ha. Herbage production over the winter on the grass-clover treatments was lower than that of the Gr250 treatment. The lower winter growth rates on the Cl150 treatment resulted in an extra 80 to $93 \mathrm{~kg}$ of silage/cow been fed in the spring period on the Cl150 treatment. Milk production was greater for the cows grazing the Cl150 and $\mathrm{Cl} 250$ treatments in mid to late lactation when sward clover content was greatest. The increase in milk production was a result of greater DMI in July, and also reduced NDF concentration and high sward clover content. The results from the current 2-yr full-lactation study suggest that the inclusion of clover in an intensive grassbased milk production system can increase milk and milk solids yield. The results of this study also indicate the potential for intensive dairy farmers to reduce $\mathrm{N}$ fertilizer inputs when clover is included into a PRG sward.

\section{ACKNOWLEDGMENTS}

The authors acknowledge the technical and farm staff at Teagasc, Animal and Grassland Research and Innovation Centre, Moorepark, Fermoy, Co. Cork for the assistance and care of the animals. This research was funded by the Irish Dairy Levy administered by Dairy Research Ireland. The first author was in receipt of a Teagasc Walsh Fellowship, Teagasc, Oak Park, Carlow, Ireland.

\section{REFERENCES}

Alexander, S., A. Black, A. Boland, J. Burke, O. T. Carton, B. S. Coulter, N. Culleton, P. Dillon, R. Hackett, and J. Humphreys. 2008. Major and micro nutrient advice for productive agricultural crops. 50th Anniversary Edition. Teagasc, Johnstown Castle, Co. Wexford, Ireland.

Andrews, M., D. Scholefield, M. T. Abberton, B. A. McKenzie, S. Hodge, and J. A. Raven. 2007. Use of white clover as an alternative to nitrogen fertiliser for dairy pastures in nitrate vulnerable zones in the UK: Productivity, environmental impact and economic considerations. Ann. Appl. Biol. 151:11-23.

AOAC. 1990. Official Methods of Analysis. Vol. 1. 15th ed. Association of Official Analytical Chemists, Washington, DC.

Beecher, M., D. Hennessy, T. M. Boland, M. McEvoy, M. O'Donovan, and E. Lewis. 2015. The variation in morphology of perennial ryegrass cultivars throughout the grazing season and effects on organic matter digestibility. Grass Forage Sci. 70:19-29.

Blaser, R. 1964. Symposium on forage utilization: Effects of fertility levels and stage of maturity on forage nutritive value. J. Anim. Sci. 23:246-253.

Brereton, A. 1995. Regional and year to year variation in production. Pages 12-22 in Irish Grasslands-Their Biology and Management. Dublin Royal Irish Academy, Dublin, Ireland.

Buxton, D. R. 1996. Quality-related characteristics of forages as influenced by plant environment and agronomic factors. Anim. Feed Sci. Technol. 59:37-49.

Chapman, D. F., J. R. Bryant, M. E. Olayemi, G. R. Edwards, B. S. Thorrold, W. H. McMillan, G. A. Kerr, G. Judson, T. Cookson, and A. Moorhead. 2017. An economically based evaluation index 
for perennial and short-term ryegrasses in New Zealand dairy farm systems. Grass Forage Sci. 72:1-21.

Clark, D. A., J. R. Caradus, R. M. Monaghan, P. Sharp, and B. S. Thorrold. 2007. Issues and options for future dairy farming in New Zealand. New Zeal. J. Agric. Res. (Lahore) 50:203-221.

Clark, D. A. and S. L. Harris. 1996. White clover or nitrogen fertiliser for dairying? Agron. Society of New Zealand No. 11/Grassland Research and Practice Series No. 6:107-114.

Cuttle, S. P., M. Hallard, G. Daniel, and R. V. Scurlock. 1992. Nitrate leaching from sheep-grazed grass/clover and fertilized grass pastures. J. Agric. Sci. 119:335-343.

Davies, A. 1992. White clover. Biologist-Institute of Biology 39:129133.

Dewhurst, R. J., R. T. Evans, N. D. Scollan, J. M. Moorby, R. J. Merry, and R. J. Wilkins. 2003. Comparison of grass and legume silages for milk production. 2. In vivo and in sacco evaluations of rumen function. J. Dairy Sci. 86:2612-2621.

Dillon, P., S. Crosse, G. Stakelum, and F. Flynn. 1995. The effect of calving date and stocking rate on the performance of springcalving dairy cows. Grass Forage Sci. 50:286-299.

Dillon, P., T. Hennessy, L. Shalloo, F. Thorne, and B. Horan. 2008 Future outlook for the Irish dairy industry: A study of international competitiveness, influence of international trade reform and requirement for change. Int. J. Dairy Technol. 61:16-29.

Dillon, P., and G. Stakelum. 1989. Herbage and dosed alkanes as a grass measurement technique for dairy cows. Irish. J. Agric. Res. (Lahore) 28:104. (Abstr.)

Egan, M., M. B. Lynch, and D. Hennessy. 2017. Including white clover in nitrogen fertilized perennial ryegrass swards: effects on dry matter intake and milk production of spring calving dairy cows. J. Agric. Sci. 155:657-668.

Enriquez-Hidalgo, D., T. Gilliland, M. H. Deighton, M. O'Donovan, and D. Hennessy. 2014a. Milk production and enteric methane emissions by dairy cows grazing fertilized perennial ryegrass pasture with or without inclusion of white clover. J. Dairy Sci. 97:1400-1412.

Enriquez-Hidalgo, D., T. J. Gilliland, and D. Hennessy. 2016. Herbage and nitrogen yields, fixation and transfer by white clover to companion grasses in grazed swards under different rates of nitrogen fertilization. Grass Forage Sci. 71:559-574.

Enriquez-Hidalgo, D., D. Hennessy, T. Gilliland, M. Egan, J. Mee, and E. Lewis. 2014b. Effect of rotationally grazing perennial ryegrass white clover or perennial ryegrass only swards on dairy cow feeding behaviour, rumen characteristics and sward depletion patterns. Livest. Sci. 169:48-62.

European Council. 2010. Directive 2010/63/EU on the protection of animals used for scientific purposes. Off. J. Eur. Union L 276.

Finneran, E., P. Crosson, P. O'Kiely, L. Shalloo, P. D. Forristal, and M. Wallace. 2012. Economic modelling of an integrated grazed and conserved perennial ryegrass forage production system. Grass Forage Sci. 67:162-176

Frame, J., and A. G. Boyd. 1987a. The effect of fertilizer nitrogen rate, white clover variety and closeness of cutting on herbage productivity from perennial ryegrass/white clover swards. Grass Forage Sci. 42:85-96.

Frame, J., and A. G. Boyd. 1987b. The effect of strategic use of fertilizer nitrogen in spring and/or autumn on the productivity of a perennial ryegrass/white clover sward. Grass Forage Sci. 42:429-438.

Frame, J., and P. Newbould. 1986. Agronomy of White Clover. Adv. Agron. 40:1-88.

Fulkerson, W. J., J. S. Neal, C. F. Clark, A. Horadagoda, K. S. Nandra, and I. Barchia. 2007. Nutritive value of forage species grown in the warm temperate climate of Australia for dairy cows: Grasses and legumes. Livest. Sci. 107:253-264.

Ganche, E., L. Delaby, M. O'Donovan, T. M. Boland, and E. Kennedy. 2013. Direct and carryover effect of post-grazing sward height on total lactation dairy cow performance. Animal 7:1390-1400.

Hameleers, A., and R. W. Mayes. 1998. The use of n-Alkanes to estimate herbage intake and diet composition by dairy cows offered a perennial ryegrass/white clover mixture. Grass Forage Sci. 53:164169
Hanrahan, L., A. Geoghegan, M. O' Donovan, V. Griffith, M. Wallace, and L. Shalloo. 2017. PastureBase Ireland: A grassland decision support system and national database. Comput. Electron. Agric. 136:193-201.

Harris, S. L., M. J. Auldist, D. A. Clark, and E. B. L. Jansen. 1998. Effect of white clover content in the diet on herbage intake, milk production and milk composition of New Zealand dairy cows housed indoors. J. Dairy Res. 65:389-400.

Harris, S. L., and D. A. Clark. 1996. Effect of high rates of nitrogen fertiliser on white clover growth, morphology, and nitrogen fixation activity in grazed dairy pasture in northern New Zealand. New Zeal. J. Agric. Res. (Lahore) 39:149-158.

Harris, S. L., D. A. Clark, M. J. Auldist, C. D. Waugh, and P. G Laboyrie. 1997b. Optimum white clover content for dairy pastures. Proc. New Zeal. Grassl. Assoc. 59:29-33.

Harris, S. L., D. A. Clark, and E. B. L. Jansen. 1997a. Optimum white clover content for milk production. Proc New Zeal Soc An. $57: 169-171$.

Harris, S. L., D. A. Clark, C. D. Waugh, and F. H. Clarkson. 1996 Nitrogen fertiliser effects on white clover in dairy pastures. Agronomy Society of New Zealand No. 11/Grassland Research and Practice Series No. 6:119-124.

Hennessy, D., M. O' Donovan, P. French, and A. S. Laidlaw. 2008 Manipulation of herbage production by altering the pattern of applying nitrogen fertilizer. Grass Forage Sci. 62:152-166.

Hoogendoorn, C. J., C. W. Holmes, and A. C. P. Chu. 1992. Some effects of herbage composition, as influenced by previous grazing management, on milk production by cows grazing on ryegrass/ white clover pastures. 2. Milk production in late spring/summer: Effects of grazing intensity during the preceding spring period. Grass Forage Sci. 47:316-325.

Humphreys, J., I. A. Casey, and A. S. Laidlaw. 2009. Comparison of milk production from clover-based and fertiliser N-based grassland on clay-loam soil under moist temperate climatic conditions. Ir. J. Agric. Food Res. 48:189-207.

Humphreys, J., K. O'Connell, and I. A. Casey. 2008. Nitrogen flows and balances in four grassland-based systems of dairy production on a clay-loam soil in a moist temperate climate. Grass Forage Sci $63: 467-480$

Kennedy, E., M. McEvoy, J. P. Murphy, and M. O'Donovan. 2009 Effect of restricted access time to pasture on dairy cow milk production, grazing behavior, and dry matter intake. J. Dairy Sci $92: 168-176$

Laidlaw, A. S. 1980. The effects of nitrogen fertilizer applied in spring on swards of ryegrass sown with four cultivars of white clover. Grass Forage Sci. 35:295-299.

Lawrence, D. C. 2015. Development of production guidelines to improve efficiency in autumn calving herds. $\mathrm{PhD}$ Thesis, School of Agriculture and Food Science, University College Dublin.

Leach, K. A., J. A. Bax, D. J. Roberts, and C. Thomas. 2000. The establishment and performance of a dairy system based on perennial ryegrass - White clover swards compared with a system based on nitrogen fertilized grass. Biol. Agric. Hortic. 17:207-227.

Ledgard, S., R. Schills, J. Eriksen, and J. Luo. 2009. Environmental impacts of grazed clover/grass pastures. Ir. J. Agric. Food Res. 48:209-226.

Ledgard, S. F., M. S. Sprosen, J. W. Penno, and G. S. Rajendram. 2001. Nitrogen fixation by white clover in pastures grazed by dairy cows: Temporal variation and effects of nitrogen fertiliser. Plant Soil 229:177-187.

Ledgard, S. F., and K. W. Steele. 1992. Biological nitrogen fixation in mixed legume/grass pastures. Plant Soil 141:137-153.

Lowman, B. G., N. Scott, and S. H. Somerville. 1973. Condition scoring of cattle. Edinburgh School of Agriculture, East of Scotland College of Agriculture.

Macduff, J. H., S. C. Jarvis, and D. H. Roberts. 1990. Nitrates: Leaching from grazed grassland systems. Pages 405-410 in Nitrates, Ag riculture, Eau. R. Calvet, ed. INRA, Paris, France.

Mayes, R. W., C. S. Lamb, and P. M. Colgrove. 1986. The use of dosed and herbage n-alkanes as markers for the determination of herbage intake. J. Agric. Sci. 107:161-170. 
McKenzie, F. R., J. L. Jacobs, P. Riffkin, G. Kearney, and M. McCaskill. 2003. Long-term effects of multiple applications of nitrogen fertiliser on grazed dryland perennial ryegrass/white clover dairy pastures in south-west Victoria. 1. Nitrogen fixation by white clover. Aust. J. Agric. Res. 54:461-469.

Minson, D. J. 1990. Forage in Ruminant Nutrition. Academic Press, Limited, London, UK.

Morgan, D., G. Stakelum, and J. Dwyer. 1989. Modified neutral detergent cellulase digestibility procedure for use with the'Fibertec'system. Irish. J. Agric. Res. (Lahore) 28:91-92.

Moseley, G., and J. R. Jones. 1984. The physical digestion of perennial ryegrass (Lolium perenne) and white clover (Trifolium repens) in the foregut of sheep. Br. J. Nutr. 52:381-390.

Nassiri, M., and A. Elgersma. 1998. Competition in perennial ryegrasswhite clover mixtures under cutting. 2. Leaf characteristics, light interception and dry matter production during regrowth. Grass Forage Sci. 53:367-379.

NRC. 2001. Nutrient Requirements for Dairy Cattle. 7th ed. National Academies Press, Washington, DC.

Nyfeler, D., O. Huguenin-Elie, M. Suter, E. Frossard, and A. Lüscher. 2011. Grass-legume mixtures can yield more nitrogen than legume pure stands due to mutual stimulation of nitrogen uptake from symbiotic and non-symbiotic sources. Agric. Ecosyst. Environ. 140:155-163.

O'Donovan, M., J. Connolly, P. Dillon, M. Rath, and G. Stakelum. 2002. Visual Assessment of Herbage Mass. Ir. J. Agric. Food Res. 41:201-211.

O'Donovan, M., E. Lewis, and P. O'Kiely. 2011. Requirements of future grass-based ruminant production systems in Ireland. Ir. J. Agric. Food Res. 50:1-21.

Patton, D., L. Shalloo, K. M. Pierce, and B. Horan. 2012. A biological and economic comparison of 2 pasture-based production systems on a wetland drumlin soil in the northern region of Ireland. J. Dairy Sci. 95:484-495.

Penno, A. 2000. Profitable milk production from pasture. Irish J. Anim. Prod. Assoc. 34:78-86.

Phelan, P., I. A. Casey, and J. Humphreys. 2013. The effect of target postgrazing height on sward clover content, herbage yield, and dairy production from grass-white clover pasture. J. Dairy Sci. 96:1598-1611.

Phillips, C. J. C. 1998. The use of individual dairy cows as replicates in the statistical analysis of their behaviour at pasture. Appl. Anim. Behav. Sci. 60:365-369.

Phillips, C. J. C., and N. L. James. 1998. The effects of including white clover in perennial ryegrass swards and the height of mixed swards on the milk production, sward selection and ingestive behaviour of dairy cows. Anim. Sci. 67:195-202.

Rattray, P. V., and J. P. Joyce. 1974. Nutritive value of white clover and perennial ryegrass. New Zeal. J. Agric. Res. (Lahore) 17:401406.

Reid, D. 1970. The effects of a wide range of nitrogen application rates on the yields from a perennial ryegrass sward with and without white clover. J. Agric. Sci. 74:227-240.

Reid, D., and M. E. Castle. 1965. The response of grass-clover and pure-grass leys to irrigation and fertiliser nitrogen treatment. J. Agric. Sci. 65:109-119.

Ribeiro Filho, H. M. N., R. Delagarde, and J. L. Peyraud. 2005. Herbage intake and milk yield of dairy cows grazing perennial ryegrass swards or white clover/perennial ryegrass swards at low- and medium-herbage allowances. Anim. Feed Sci. Technol. 119:13-27.

Riberio Filho, H. M. N., R. Delagarde, and J. L. Peyruad. 2003. Inclusion of white clover in strip-grazed perennial ryegrass swards: herbage intake and milk yield of dairy cows at different ages of sward regrowth. Anim. Sci. 77:499-510.
Salaün, C., W. M. van Straalen, J. Kosut, J. L. Peyraud, and A. M. van Vuuren. 1999. In situ degradation of perennial rye grass from grazed pastures during the season at two levels of nitrogen fertilization. Ann. Zootech. 48:35-46.

Schils, R. L. M., T. J. Boxem, C. J. Jagtenberg, and M. C. Verboon. 2000. The performance of a white clover based dairy system in comparison with a grass/fertiliser-N system. II. Animal production, economics and environment. Wageningen J. Life Sci. 48:305-318.

Schils, R. L. M., T. V. Vellinga, and T. Kraak. 1999. Dry-matter yield and herbage quality of a perennial ryegrass/white clover sward in a rotational grazing and cutting system. Grass Forage Sci. 54:19-29.

Teagasc. 2009. Grazing Notebook. Accessed May 12, 2016. https:// www.opt-in.ie/static/GrazingNotebook.pdf.

Thomson, D. J. 1984. The nutritive value of white clover. Pages 78-92 in Proc. Forage Legumes. Occasional Symposium. British Grassland Society, Berkshire, UK.

Thomson, D. J., D. E. Beever, M. J. Haines, S. B. Cammell, R. T. Evans, M. S. Dhanoa, and A. R. Austin. 1985. Yield and composition of milk from Friesian cows grazing either perennial ryegrass or white clover in early lactation. J. Dairy Res. 52:17-31.

Thomson, D. J., and W. F. Raymond. 1970. White clover in animal production: nutritional factors: A review. Pages 277-284 in Proc. Occasional Symposium 6 of the British Grassland Society.

Ulyatt, M., J. Lancashire, and W. Jones. 1977. The nutritive value of legumes. Proc. New Zeal. Grassl. Assoc. 38:107-118.

Ulyatt, M. J. 1981. The feeding value of temperate pastures. Anim. Sci. B1:125-141.

Ulyatt, M. J., D. J. Thomson, D. E. Beever, R. T. Evans, and M. J. Haines. 1988. The digestion of perennial ryegrass (Lolium perenne cv. Melle) and white clover (Trifolium repens cv. Blanca) by grazing cattle. Br. J. Nutr. 60:137-149.

Van Soest, P. J. 1994. Nutritional Ecology of the Ruminant. Cornell University Press, Ithaca, NY.

Van Soest, P. J., J. B. Robertson, and B. A. Lewis. 1991. Methods for dietary fiber, neutral detergent fiber, and nonstarch polysaccharides in relation to animal nutrition. J. Dairy Sci. 74:3583-3597.

Whitehead, D. C. 1995. Grassland nitrogen. CAB International.

Williams, T. A., D. R. Evans, I. Rhodes, and M. T. Abberton. 2003. Long-term performance of white clover varieties grown with perennial ryegrass under rotational grazing by sheep with different nitrogen applications. J. Agric. Sci. 140:151-159.

Wilman, D., and P. A. Hollington. 1985. Effects of white clover and fertilizer nitrogen on herbage production and chemical composition and soil water. J. Agric. Sci. 104:453-467.

Wilson, J., and P. Kennedy. 1996. Plant and animal constraints to voluntary feed intake associated with fibre characteristics and particle breakdown and passage in ruminants. Aust. J. Agric. Res. 47:199-225.

Wims, C. M., L. Delaby, T. M. Boland, and M. O'Donovan. 2014. Effect of pre-grazing herbage mass on dairy cow performance, grass dry matter production and output from perennial ryegrass (Lolium perenne L.) pastures. Animal 8:141-151.

Wims, C. M., M. McEvoy, L. Delaby, T. M. Boland, and M. O'Donovan. 2013. Effect of perennial ryegrass (Lolium perenne L.) cultivars on the milk yield of grazing dairy cows. Animal 7:410-421.

Woodward, S. L., K. A. MacDonald, W. A. Carter, J. P. J. Eerens, and J. R. Crush. 2001. Milksolids production from different combinations of perennial ryegrass and white clover cultivars: II Milksolids production and farm profitability. Proc. New Zeal. Grassl. Assoc. 97-102.

Yu, Y.-W., Z. B. Nan, and C. Matthew. 2008. Population relationships of perennial ryegrass and white clover mixtures under differing grazing intensities. Agric. Ecosyst. Environ. 124:40-50. 